\title{
GMR
}

\section{IL-8 -251A/T polymorphism contributes to coronary artery disease susceptibility in a Chinese population}

\author{
R.J. Zhang ${ }^{1}$, X.D. Li ${ }^{1}$, S.W. Zhang', X.H. Li ${ }^{1}$ and L. Wu ${ }^{2}$ \\ ${ }^{1}$ Department of Cardiovascular Medicine, People's Hospital of Linyi City, \\ Linyi, China \\ ${ }^{2}$ Department of Cardiovascular Internal Medicine, Zhengzhou People's Hospital, \\ Zhengzhou, China \\ Corresponding author: S.W. Zhang \\ E-mail: zhangsw_zsw@126.com
}

Genet. Mol. Res. 16 (1): gmr16018224

Received January 4, 2016

Accepted August 4, 2016

Published February 16, 2017

DOI http://dx.doi.org/10.4238/gmr16018224

Copyright $(2017$ The Authors. This is an open-access article distributed under the terms of the Creative Commons Attribution ShareAlike (CC BY-SA) 4.0 License.

\begin{abstract}
Interleukin-8 (IL-8) is a mediator of inflammation and plays an important role in regulating immune responses. To date, several studies have tested the association between $I L-8$ gene polymorphisms and development of coronary artery disease (CAD), but their results have proved to be inconsistent. We conducted an investigation to assess the relationship between the $I L-8-251 \mathrm{~A} / \mathrm{T}$ (rs4073) sequence variant and CAD in a Chinese population. Between April 2013 and January 2015, 217 patients with coronary angiography-confirmed CAD were enrolled in our study, along with 245 control subjects. $I L-8-251 \mathrm{~A} / \mathrm{T}$ genotyping was performed using a polymerase chain reaction-restriction fragment length polymorphism assay. A chi-square test revealed that $I L-8-251 \mathrm{~A} /$ $\mathrm{T}$ genotype distributions significantly differed between CAD patients and control subjects (chi-square $=8.29, \mathrm{P}<0.02$ ). Moreover, multiplelogistic regression analysis showed that individuals carrying TA [odds ratio $(\mathrm{OR})=1.59,95 \%$ confidence interval $(\mathrm{CI})=1.01-2.57]$ and $\mathrm{AA}$
\end{abstract}

Genetics and Molecular Research 16 (1): gmr16018224 
$(\mathrm{OR}=2.06,95 \% \mathrm{CI}=1.21-3.52)$ genotypes were at increased risk of CAD compared to those with the TT genotype. Under dominant (OR $=1.75,95 \% \mathrm{CI}=1.13-2.73)$ and recessive $(\mathrm{OR}=1.54,95 \% \mathrm{CI}=1.02$ 2.37 ) genetic models, the $I L-8-251 \mathrm{~A} / \mathrm{T}$ polymorphism also significantly correlated with CAD. In conclusion, our results suggest that this variant is an independent risk factor for CAD development under codominant, dominant, and recessive models.

Key words: $I L-8-251 \mathrm{~A} / \mathrm{T}$; rs4073; Coronary artery disease; Polymorphism

\section{INTRODUCTION}

Cardiovascular disease is associated with high mortality and morbidity worldwide, and its incidence has been increasing in China recently (Ding et al., 2015). Coronary artery disease (CAD), caused by atherosclerosis, is the most common type of cardiovascular disease. The etiology of CAD is a long-term process involving many lifestyle factors and their interactions, including diet, hypertension, hypercholesterolemia, diabetes, obesity, and lack of physical activity (Campbell et al., 1998; Lindahl et al., 2000; Erbel and Görge, 2014; Bosevski and Lazarova-Trajkovska, 2015). However, not all individuals exposed to such risks develop $\mathrm{CAD}$; therefore, it is thought that hereditary factors contribute to the pathology of this disease.

The $I L-8$ gene is located on chromosome 4q13-q21, and comprises four exons, three introns, and a proximal promoter region (Mukaida et al., 1989). IL-8 plays an important role in regulating both inflammatory and immune processes (Modi et al., 1990; Gura, 1996). To date, several studies have examined the association between $I L-8$ gene polymorphisms and risk of CAD and myocardial infarction, but with conflicting results (Vogiatzi et al., 2008; Ren and She, 2015; Wang et al., 2015). Therefore, we conducted the current investigation to assess the relationship between the $I L-8-251 \mathrm{~A} / \mathrm{T}$ (rs4073) sequence variation and development of CAD in a Chinese population.

\section{MATERIAL AND METHODS}

\section{Subjects}

Between April 2013 and January 2015, 217 CAD patients were recruited from the First Department of Cardiovascular Internal Medicine of Zhengzhou People's Hospital and the People's Hospital of Linyi City. All patient diagnoses were confirmed by coronary angiography. Over the same period, 245 control subjects were randomly selected among individuals attending our hospital for a regular health examination. Using coronary angiography, all participants in this group were confirmed to be free of cardiovascular diseases, including CAD. Patients and controls with serious infectious diseases, severe heart failure, malignant tumors, dilated or hypertrophic cardiomyopathy, or serious kidney or liver diseases were excluded. Lifestyle habits of study participants and certain clinical data were ascertained using a selfdesigned questionnaire concerning gender, age, family history of CAD, tobacco smoking, alcohol consumption, body mass index (BMI), hypertension, and diabetes. Serum biochemical data were collected from medical records, and comprised levels of total cholesterol (TC),

Genetics and Molecular Research 16 (1): gmr16018224 
triglycerides (TGs), and high- (HDL-C) and low-density lipoprotein cholesterol (LDL-C).

This study was performed with the permission of the Institutional Review Board of Zhengzhou People's Hospital and the People's Hospital of Linyi City. Written informed consent was obtained from all subjects prior to participation.

\section{Genotyping}

A blood sample $(5 \mathrm{~mL})$ was obtained from each participant and stored at $-20^{\circ} \mathrm{C}$ until use. Isolation of genomic DNA was carried out using a TIANamp blood DNA kit (Tiangen, Beijing, China), and genotyping of $I L-8-251 \mathrm{~A} / \mathrm{T}$ was performed with a polymerase chain reaction (PCR)-restriction fragment length polymorphism assay. Primer Express 2.0 (Applied Biosystems, Foster City, CA, USA) was used to design the following PCR primers targeting the $I L-8$ region containing the $-251 \mathrm{~A} / \mathrm{T}$ variation: forward, 5'-TGC CCC TTC ACT CTG TTA AC-3'; and reverse, 5'-GAA GTC CCA CAA TTT GGT G-3'. PCRs were carried out under the following conditions: denaturation at $95^{\circ} \mathrm{C}$ for $5 \mathrm{~min}$, then 35 cycles of denaturation at $94^{\circ} \mathrm{C}$ for $30 \mathrm{~s}$, annealing at $58^{\circ} \mathrm{C}$ for $30 \mathrm{~s}$, and extension at $72^{\circ} \mathrm{C}$ for $30 \mathrm{~s}$, before a final extension at $72^{\circ} \mathrm{C}$ for $7 \mathrm{~min}$. PCR products were kept at $4^{\circ} \mathrm{C}$ until needed. Amplified fragments of the region containing the $I L-8-251 \mathrm{~A} / \mathrm{T}$ polymorphism were subsequently digested with the restriction enzyme $M f e$ I. Digestion products were visualized under ultraviolet light.

\section{Statistical analysis}

Chi-square tests were carried out to assess differences between CAD patients and control subjects with respect to lifestyle and clinical characteristics, including serum measurements. Hardy-Weinberg equilibrium (HWE) was determined by the chi-square test. Multivariate logistic regression analyses were also conducted, in which single-putative risk factors were analyzed to determine crude odds ratios (ORs) and 95\% confidence intervals (CIs). Multiple-logistic regression analysis was carried out to adjust for potential confounding factors. All statistical analyses were achieved using SPSS version 16.0 (SPSS Inc., Chicago, IL, USA). P values $<0.05$ were considered statistically significant.

\section{RESULTS}

The lifestyle and clinical characteristics of patients and control subjects are presented in Table 1. The two groups were comparable in terms of age (chi-square $=3.10, \mathrm{P}=0.08$ ), alcohol consumption (chi-square $=3.55, \mathrm{P}=0.06$ ), and family history of CAD (chi-square $=$ $0.54, \mathrm{P}=0.46)$. Using chi-square tests, significant differences were observed between CAD patients and control subjects with respect to gender (chi-square $=4.80, \mathrm{P}=0.03$ ), BMI (chisquare $=16.35, \mathrm{P}<0.01$ ), hypertension (chi-square $=27.57, \mathrm{P}<0.01$ ), diabetes (chi-square $=$ $5.16, \mathrm{P}=0.02$ ), tobacco smoking (chi-square $=9.66, \mathrm{P}=0.002$ ), and levels of TC (chi-square $=6.96, \mathrm{P}<0.05), \mathrm{TG}($ chi-square $=4.33, \mathrm{P}<0.05), \mathrm{HDL}-\mathrm{C}($ chi-square $=2.36, \mathrm{P}=0.01)$, and LDL-C (chi-square $=6.58, \mathrm{P}<0.05)$.

Distributions of $I L-8-251 \mathrm{~A} / \mathrm{T}$ genotypes are shown in Table 2. In total, $47(21.66 \%)$, $101(46.54 \%)$, and $69(31.80 \%)$ CAD patients, and $80(32.65 \%), 108(44.08 \%)$, and 57 (23.27\%) control subjects carried TT, TA, and AA genotypes, respectively. The chi-square test revealed a statistically significant difference in genotype distributions between patients

Genetics and Molecular Research 16 (1): gmr16018224 
and controls (chi-square $=8.29, \mathrm{P}=0.02$ ). Moreover, $I L-8-251 \mathrm{~A} / \mathrm{T}$ genotype frequencies were consistent with HWE, with P values of 0.38 and 0.08 for the CAD and control groups, respectively.

\begin{tabular}{|c|c|c|c|c|c|c|}
\hline Characteristic & Patients $(\mathrm{N}=217)$ & $\%$ & Controls $(\mathrm{N}=245)$ & $\%$ & Chi-square & $\mathrm{P}$ \\
\hline \multicolumn{7}{|l|}{ Gender } \\
\hline Female & 74 & 34.10 & 108 & 44.08 & & \\
\hline Male & 143 & 65.90 & 137 & 55.92 & 4.80 & 0.03 \\
\hline \multicolumn{7}{|l|}{ Age (years) } \\
\hline$<50$ & 129 & 59.45 & 165 & 67.35 & & \\
\hline$\geq 50$ & 88 & 40.55 & 80 & 32.65 & 3.10 & 0.08 \\
\hline \multicolumn{7}{|l|}{ BMI $\left(\mathrm{kg} / \mathrm{m}^{2}\right)$} \\
\hline$<24$ & 84 & 38.71 & 141 & 57.55 & & \\
\hline$\geq 24$ & 133 & 61.29 & 104 & 42.45 & 16.35 & $<0.01$ \\
\hline \multicolumn{7}{|l|}{ Hypertension } \\
\hline No & 103 & 47.47 & 175 & 71.43 & & \\
\hline Yes & 114 & 52.53 & 70 & 28.57 & 27.57 & $<0.01$ \\
\hline \multicolumn{7}{|l|}{ Diabetes } \\
\hline No & 178 & 82.03 & 219 & 89.39 & & \\
\hline Yes & 39 & 17.97 & 26 & 10.61 & 5.16 & 0.02 \\
\hline \multicolumn{7}{|c|}{ Tobacco smoking } \\
\hline No & 125 & 57.60 & 175 & 71.43 & & \\
\hline Yes & 92 & 42.40 & 70 & 28.57 & 9.66 & 0.002 \\
\hline \multicolumn{7}{|c|}{ Alcohol consumption } \\
\hline No & 140 & 64.52 & 178 & 72.65 & & \\
\hline Yes & 77 & 35.48 & 67 & 27.35 & 3.55 & 0.06 \\
\hline \multicolumn{7}{|c|}{ Family history of CAD } \\
\hline No & 206 & 94.93 & 236 & 96.33 & & \\
\hline Yes & 11 & 5.07 & 9 & 3.67 & 0.54 & 0.46 \\
\hline $\mathrm{TC}$ & & $195.35 \pm 32.42$ & & $174.62 \pm 31.56$ & 6.96 & $<0.05$ \\
\hline$\overline{\mathrm{TG}}$ & & $132.54 \pm 38.42$ & & $118.36 \pm 31.90$ & 4.33 & $<0.05$ \\
\hline$\overline{\text { HDL-C }}$ & & $40.23 \pm 17.42$ & & $43.45 \pm 11.56$ & 2.36 & 0.01 \\
\hline$\overline{\text { LDL-C }}$ & & $117.72 \pm 20.45$ & & $104.52 \pm 22.42$ & 6.58 & $<0.05$ \\
\hline
\end{tabular}

$\mathrm{BMI}=$ body mass index, $\mathrm{CAD}=$ coronary artery disease, $\mathrm{TC}=$ total cholesterol, $\mathrm{TG}=$ triglycerides, $\mathrm{HDL}-\mathrm{C}=$ high density lipoprotein cholesterol, LDL-C = low-density lipoprotein cholesterol.

Table 2. Distribution of $I L-8-251 \mathrm{~A} / \mathrm{T}$ genotypes in coronary artery disease patients and control subjects.

\begin{tabular}{l|c|c|c|c|c|c|c|c}
\hline Genotype & Patients (N=217) & $\%$ & Controls (N = 245) & $\%$ & Chi-square & P & \multicolumn{2}{|c}{ P for HWE } \\
\cline { 6 - 9 } & & & & & & & Patients & Controls \\
\hline TT & 47 & 21.66 & 80 & 32.65 & & & & \\
\hline TA & 101 & 46.54 & 108 & 44.08 & & & & 0.08 \\
\hline AA & 69 & 31.80 & 57 & 23.27 & 8.29 & 0.02 & 0.38 & 0.02 \\
\hline
\end{tabular}

HWE $=$ Hardy-Weinberg equilibrium.

Multiple-logistic regression analysis showed that individuals carrying the TA $(\mathrm{OR}=$ $1.59,95 \% \mathrm{CI}=1.01-2.57)$ and $\mathrm{AA}(\mathrm{OR}=2.06,95 \% \mathrm{CI}=1.21-3.52)$ genotypes of $I L-8-251 \mathrm{~A} / \mathrm{T}$ were at increased risk of CAD compared to those with the TT genotype (Table 3). Under a dominant model, the TA+AA genotype showed a statistically significant correlation with CAD compared to the TT genotype $(\mathrm{OR}=1.75,95 \% \mathrm{CI}=1.13-2.73)$, whereas under a recessive model, the AA genotype was significantly associated with CAD risk compared to the TT+TA genotype $(\mathrm{OR}=1.54,95 \% \mathrm{CI}=1.02-2.37)$.

Genetics and Molecular Research 16 (1): gmr16018224 
Table 3. Association between the $I L-8-251 \mathrm{~A} / \mathrm{T}$ genetic polymorphism and development of coronary artery disease assessed by multiple-logistic regression analysis.

\begin{tabular}{|c|c|c|c|c|c|c|}
\hline Model and genotype & Patients $(\mathrm{N}=217)$ & $\%$ & Controls $(\mathrm{N}=245)$ & $\%$ & OR $(95 \% \mathrm{CI})^{1}$ & $\mathrm{P}$ \\
\hline \multicolumn{7}{|l|}{ Codominant } \\
\hline TT & 47 & 21.66 & 80 & 32.65 & 1.0 (Ref.) & - \\
\hline TA & 101 & 46.54 & 108 & 44.08 & $1.59(1.01-2.57)$ & 0.04 \\
\hline $\mathrm{AA}$ & 69 & 31.8 & 57 & 23.27 & $2.06(1.21-3.52)$ & 0.005 \\
\hline \multicolumn{7}{|l|}{ Dominant } \\
\hline TT & 47 & 21.66 & 80 & 32.65 & 1.0 (Ref.) & - \\
\hline $\mathrm{TA}+\mathrm{AA}$ & 170 & 78.34 & 165 & 67.35 & $1.75(1.13-2.73)$ & 0.008 \\
\hline \multicolumn{7}{|l|}{ Recessive } \\
\hline $\mathrm{TT}+\mathrm{TA}$ & 148 & 68.2 & 188 & 76.73 & 1.0 (Ref.) & - \\
\hline AA & 69 & 31.8 & 57 & 23.27 & $1.54(1.02-2.37)$ & 0.04 \\
\hline
\end{tabular}

${ }^{1}$ Adjusted for gender, age, body mass index, hypertension, diabetes, tobacco smoking, total cholesterol, triglycerides, and high- and low-density lipoprotein cholesterol. $\mathrm{OR}=$ odds ratio, $\mathrm{CI}=$ confidence interval, Ref. = reference.

\section{DISCUSSION}

Here, we report the results of a case-control study investigating the association between the $I L-8-251 \mathrm{~A} / \mathrm{T}$ polymorphism and CAD risk, in which this variant was found to correlate with this disease under codominant, dominant, and recessive models.

IL-8 promotes the production of other cytokines. IL-1, TNF- $\alpha$, LPS, and phorbol myristate acetate can induce the synthesis and secretion of IL- 8 by monocytes, macrophages, fibroblasts, and endothelial cells (Hébert et al., 1990; Mielke et al., 1990; Strieter et al., 1990). Rus et al. (1996) reported that IL-8 expression can be induced by complement activation, and that this may contribute to the increased IL-8 levels found in atherosclerotic vessel walls. Moreover, this chemokine is involved in inflammation during the initiation and progression of atherosclerosis. IL-8 production remains elevated for an extended period during acute inflammation, whereas other inflammatory cytokines are cleared within a few hours (DeForge et al., 1992; Shebuski and Kilgore, 2002). Liu et al. (1997) suggested that IL-8 contributes to the recruitment of T lymphocytes and smooth muscle cells to the subendothelial space and has a major role in the formation of atherosclerotic lesions, whereas Nair et al. (2014) showed that $I L-8$ gene expression is a predictor of cardiovascular risk. Therefore, IL-8 may play a role in the pathogenesis of atherosclerosis, and thus appears to be associated with the development of CAD.

Previous studies have demonstrated that sequence variations in this gene are associated with CAD, but their results have been inconsistent (Vogiatzi et al., 2008; He et al., 2014; Ren and She, 2015; Yang et al., 2015). Vogiatzi et al. (2008) conducted an investigation into the influence of common $I L-8$ polymorphisms on CAD risk, showing a combination of the $-251 \mathrm{~A} /$ $\mathrm{T}$ and $-781 \mathrm{C} / \mathrm{T}$ variants to be associated with susceptibility to this disease. However, He et al. (2014) and Ren and She (2015) failed to establish a link between the -251A/T polymorphism and CAD risk, and a similar result was obtained by Yang et al. (2015) in a study of several IL gene variants. In the present study, we found this same polymorphism to be independently associated with increased risk of CAD. Such discrepancies may be the result of differences in study populations, selection of patients and control subjects, or sample sizes.

In conclusion, our findings suggest that the $I L-8-251 \mathrm{~A} / \mathrm{T}$ polymorphism constitutes an independent risk factor for the development of CAD under codominant, dominant, and recessive models. Further studies with large sample sizes including subjects of various ethnicities are greatly needed to confirm our results. 


\title{
Conflicts of interest
}

The authors declare no conflict of interest.

\section{ACKNOWLEDGMENTS}

\author{
We thank for the great help and support from People's Hospital of Linyi City.
}

\section{REFERENCES}

Bosevski M and Lazarova-Trajkovska E (2015). Carotid artery disease in patients with type 2 diabetes. Angiol. Sosud. Khir. 21: 17-26.

Campbell TC, Parpia B and Chen J (1998). Diet, lifestyle, and the etiology of coronary artery disease: the Cornell China study. Am. J. Cardiol. 82 (10B): 18T-21T. http://dx.doi.org/10.1016/S0002-9149(98)00718-8

DeForge LE, Fantone JC, Kenney JS and Remick DG (1992). Oxygen radical scavengers selectively inhibit interleukin 8 production in human whole blood. J. Clin. Invest. 90: 2123-2129. http://dx.doi.org/10.1172/JCI116097

Ding D, Wang M, Su D, Hong C, et al. (2015). Body mass index, high-sensitivity C-reactive protein and mortality in Chinese with coronary artery disease. PLoS One 10: e0135713.http://dx.doi.org/10.1371/journal.pone.0135713

Erbel R and Görge G (2014). New insights in pathogenesis and etiology of coronary artery disease. Dtsch. Med. Wochenschr. 139 (Suppl 1): S4-S8.

Gura T (1996). Chemokines take center stage in inflammatory ills. Science 272: 954-956. http://dx.doi.org/10.1126/ science.272.5264.954

He F, Teng X, Gu H, Liu H, et al. (2014). Interleukin-6 receptor rs 7529229 T/C polymorphism is associated with left main coronary artery disease phenotype in a Chinese population. Int. J. Mol. Sci. 15: 5623-5633. http://dx.doi.org/10.3390/ ijms 15045623

Hébert CA, Luscinskas FW, Kiely JM, Luis EA, et al. (1990). Endothelial and leukocyte forms of IL-8. Conversion by thrombin and interactions with neutrophils. J. Immunol. 145: 3033-3040.

Lindahl B, Toss H, Siegbahn A, Venge P, et al. (2000). Markers of myocardial damage and inflammation in relation to long-term mortality in unstable coronary artery disease. FRISC Study Group. Fragmin during Instability in Coronary Artery Disease. N. Engl. J. Med. 343: 1139-1147. http://dx.doi.org/10.1056/NEJM200010193431602

Liu Y, Hultén LM and Wiklund O (1997). Macrophages isolated from human atherosclerotic plaques produce IL-8, and oxysterols may have a regulatory function for IL-8 production. Arterioscler. Thromb. Vasc. Biol. 17: 317-323. http:// dx.doi.org/10.1161/01.ATV.17.2.317

Mielke V, Bauman JG, Sticherling M, Ibs T, et al. (1990). Detection of neutrophil-activating peptide NAP/IL-8 and NAP/ IL-8 mRNA in human recombinant IL-1 alpha- and human recombinant tumor necrosis factor-alpha-stimulated human dermal fibroblasts. An immunocytochemical and fluorescent in situ hybridization study. J. Immunol. 144: 153-161.

Modi WS, Dean M, Seuanez HN, Mukaida N, et al. (1990). Monocyte-derived neutrophil chemotactic factor (MDNCF/IL8) resides in a gene cluster along with several other members of the platelet factor 4 gene superfamily. Hum. Genet. 84: 185-187. http://dx.doi.org/10.1007/BF00208938

Mukaida N, Shiroo M and Matsushima K (1989). Genomic structure of the human monocyte-derived neutrophil chemotactic factor IL-8. J. Immunol. 143: 1366-1371.

Nair J, Shanker J, Jambunathan S, Arvind P, et al. (2014). Expression analysis of leukotriene-inflammatory gene interaction network in patients with coronary artery disease. J. Atheroscler. Thromb. 21: 329-345. http://dx.doi.org/10.5551/ 迆.20123

Ren B and She Q (2015). Study on the association between $I L-1 b, I L-8$ and $I L-10$ gene polymorphisms and risk of coronary artery disease. Int. J. Clin. Exp. Med. 8: 7937-7943.

Rus HG, Vlaicu R and Niculescu F (1996). Interleukin-6 and interleukin-8 protein and gene expression in human arterial atherosclerotic wall. Atherosclerosis 127: 263-271. http://dx.doi.org/10.1016/S0021-9150(96)05968-0

Shebuski RJ and Kilgore KS (2002). Role of inflammatory mediators in thrombogenesis. J. Pharmacol. Exp. Ther. 300: 729-735. http://dx.doi.org/10.1124/jpet.300.3.729

Strieter RM, Chensue SW, Basha MA, Standiford TJ, et al. (1990). Human alveolar macrophage gene expression of interleukin- 8 by tumor necrosis factor-alpha, lipopolysaccharide, and interleukin-1 beta. Am. J. Respir. Cell Mol. Biol. 2: 321-326. http://dx.doi.org/10.1165/ajrcmb/2.4.321

Genetics and Molecular Research 16 (1): gmr16018224 
Vogiatzi K, Apostolakis S, Voudris V, Thomopoulou S, et al. (2008). Interleukin 8 and susceptibility to coronary artery disease: a population genetics perspective. J. Clin. Immunol. 28: 329-335. http://dx.doi.org/10.1007/s10875-008-9194-3

Wang S, Dai YX, Chen LL, Jiang T, et al. (2015). Effect of IL-1b, IL-8, and IL-10 polymorphisms on the development of myocardial infarction. Genet. Mol. Res. 14: 12016-12021.http://dx.doi.org/10.4238/2015.October.5.14

Yang HT, Wang SL, Yan LJ, Qian P, et al. (2015). Association of interleukin gene polymorphisms with the risk of coronary artery disease. Genet. Mol. Res. 14: 12489-12496. http://dx.doi.org/10.4238/2015.October.16.16

Genetics and Molecular Research 16 (1): gmr16018224 